\title{
The effects of drainage on the behaviour of railway track foundation materials during cyclic loading
}

\author{
A. MAMOU*, W. POWRIE*, J. A. PRIEST $\dagger$ and C. CLAYTON*
}

\begin{abstract}
This paper presents the results of a series of hollow cylinder tests carried out to investigate the role of drainage conditions on the response of railway track foundation materials during cyclic loading. Three sand-clay mixes were tested. It was found that, below a certain cyclic shear stress threshold, and depending on the drainage conditions, changes in principal stress direction should not adversely affect the cyclic stability of a railway foundation. However, significant stiffness degradation and failure may occur if this cyclic shear stress threshold is exceeded. The cyclic shear stress threshold increased with moderate additions of clay per unit volume of sand, and reduced significantly when specimen drainage was prevented. For the materials tested, the cyclic shear stress threshold in free-to-drain conditions was generally similar to the cyclic shear stress in the soil immediately below a $0.3 \mathrm{~m}$ deep ballast bed, but comfortably greater than the cyclic stress at a depth of $1 \mathrm{~m}$ below the sleeper base. In undrained conditions, the cyclic shear stress threshold was generally similar to the cyclic shear stress at a depth of $1 \mathrm{~m}$ below the sleeper base. This has implications for the suitability of such materials for railway track foundations.
\end{abstract}

KEYWORDS: laboratory tests; pore pressures; repeated loading; stiffness; torsion

\section{BACKGROUND}

Railway track foundation materials play an essential role in ensuring the stability of the track structure and maintaining track geometry. During their operational life they are subject to repeated loading cycles, which under unfavourable conditions can result in the accumulation of unacceptably large plastic strains and a reduction in resilient stiffness. Both of these can significantly reduce the life of the track.

A number of studies have investigated the behaviour of railway track foundations under repeated loading (e.g. Brown et al., 1975; O'Reilly et al., 1991; Shahu et al., 1999; Chung Ip et al., 2012). It has generally been observed (Brown \& Selig, 1991) that there is a threshold stress level above which significant accumulation of plastic strain and (in undrained conditions) generation of excess pore pressure occurs. Below this threshold stress, changes in cyclic strain and pore pressure are very small or negligible. A different approach has been adopted in investigating the dynamic response of soils to seismic loading (Georgiannou et al., 1991; Mortezaie \& Vucetic, 2016), which identifies a threshold strain beyond which significant changes in stiffness, strength and pore pressure are observed. However, for railway foundations the applied stresses are more easily quantified than the resulting strains; hence the threshold stress approach is usually adopted.

Although a number of investigations have considered the effects of cyclic loading on soil behaviour, relatively few have addressed the combined effects of the horizontal and vertical stress changes to which railway track foundation soils are subjected, and result in principal stress rotation (PSR) (Brown, 1996). Field measurements have shown that,

Manuscript received 15 December 2015; revised manuscript accepted 18 January 2017. Published online ahead of print 23 February 2017.

Discussion on this paper closes on 1 March 2018, for further details see p. ii.

Published with permission by the ICE under the CC-BY license. (http://creativecommons.org/licenses/by/4.0/)

${ }^{*}$ University of Southampton, Southampton, UK.

$\uparrow$ University of Calgary, Calgary, Alberta, Canada. although vertical stress changes attenuate with depth, horizontal stress changes become more pronounced up to a certain depth below the sleeper base before then reducing with further increases in depth (Priest et al., 2010).

Laboratory studies where PSR has been considered show a higher rate of plastic strain accumulation than that exhibited when only the vertical stress is cycled (Chan \& Brown, 1994; Momoya et al., 2007). In more recent work on saturated materials (Gräbe \& Clayton, 2009), very large increases in permanent strain have been observed, associated with pore pressure increases, when PSRs have been applied in undrained conditions. Permanent deformations and pore pressures resulting from PSR were found to reduce as the clay content of the material was increased. In addition, the difference induced by PSR was greater at higher peak effective principal stress ratios. Gräbe \& Clayton (2014) also observed that, in undrained loading of saturated materials, PSR caused the resilient modulus of the mixes investigated to reduce by some $20-26 \%$ compared with tests in which only the vertical stress was cycled. Cyclic changes in the direction of principal stresses are therefore likely to influence significantly the observed resilient behaviour of soils.

Owing to the limited amount of laboratory test data available, uncertainties remain in our understanding of the stress paths, drainage conditions and magnitudes of cyclic stress for which PSR may be important for the long-term performance of railway track foundations. The aim of the research reported in this paper was to investigate these, with an emphasis on the relative magnitudes of the cycles of shear and normal stress and on the drainage conditions specifically, the time available for drainage between successive loading peaks, as governed by the permeability of the material and the drainage path length.

\section{EXPERIMENTAL METHOD \\ Apparatus}

The laboratory tests were carried out using a hollow cylinder apparatus (HCA). In the HCA a rotation in the direction of principal stresses can be achieved by applying an 
Table 1. Compositions of materials A to C (as a percentage of total dry sample weight) as formulated by Gräbe \& Clayton (2014)

\begin{tabular}{|c|c|c|c|c|}
\hline \multirow[b]{2}{*}{ Component } & \multirow[b]{2}{*}{ Grain size range } & \multicolumn{3}{|c|}{ Reconstituted material } \\
\hline & & A & B & $\mathrm{C}$ \\
\hline & & \multicolumn{3}{|c|}{ Percentage of total by dry weight: $\%$} \\
\hline Sand (Leighton Buzzard) & Fraction B $600-1 \cdot 180 \mu \mathrm{m}$ & 51 & 47 & 43 \\
\hline$G_{\mathrm{s}}=2.65$ & Fraction C $300-600 \mu \mathrm{m}$ & 11 & 10 & 9 \\
\hline & Fraction D $150-300 \mu \mathrm{m}$ & 11 & 10 & 9 \\
\hline Silt (HPF5) & $5-150 \mu \mathrm{m}$ & 19 & 21 & 23 \\
\hline$G_{\mathrm{s}}=2 \cdot 65$ & & & & \\
\hline \multirow{3}{*}{$\begin{array}{r}\text { Clay (HPC) } \\
G_{\mathrm{s}}=2 \cdot 60\end{array}$} & $<125 \mu \mathrm{m}$ & 8 & 13 & 16 \\
\hline & & & & \\
\hline & & \multicolumn{3}{|c|}{ Resulting composition of mixes: $\%$} \\
\hline Sand content & & 79 & 73 & 68 \\
\hline Silt content & & 14 & 16 & 18 \\
\hline Clay content & & 7 & 11 & 14 \\
\hline
\end{tabular}

axial twist (torque), which induces shear stresses on horizontal and complementary radial planes. However, because the thickness is finite, application of the torque results in non-uniform stress and strain distributions across the specimen wall. These non-uniformities and their effects can be reduced to acceptable levels by selecting an appropriate specimen geometry (Saada \& Townsend, 1981; Sayao \& Vaid, 1991) and adopting the Hight et al. (1983) framework of average stresses and strains for analysis (Zdravkovic \& Jardine, 1997; Nishimura et al., 2007; Georgiannou et al., 2008; Cai et al., 2013). The specimens used in this research had an outer diameter of $\sim 100 \mathrm{~mm}$, an inner diameter of $\sim 60 \mathrm{~mm}$ and a height of $\sim 200 \mathrm{~mm}$, thereby satisfying the geometric criteria of both Saada \& Townsend (1981) and Sayao \& Vaid (1991).

In the tests reported in this paper, the stresses were corrected to take into account the effect of membrane restraint using the approach given by Tatsuoka et al. (1986; their equations (8)-(10)). Membrane penetration effects were insignificant, because the specimens were well graded, prepared at relatively high dry densities and tested at low effective stresses with constant inner and outer cell pressures. Keeping the inner and outer cell pressures equal also avoids stress/strain non-uniformities arising from changes in the curvature of the specimen wall.

The resilient modulus of a soil is the stiffness calculated from the recoverable (i.e. resilient) strains under repeated loading/unloading (equation (1)). In the HCA, it is equivalent to the resilient Young's modulus and is given the symbol $E_{\mathrm{r}}$

$$
E_{\mathrm{r}}=q_{\mathrm{r}} / \varepsilon_{\mathrm{a}, \mathrm{r}}
$$

where $q_{\mathrm{r}}$ is the cyclic deviator stress and $\varepsilon_{\mathrm{a}, \mathrm{r}}$ is the recoverable axial cyclic strain.

Axial strains were measured locally on the specimen to eliminate errors associated with the misalignment of specimen ends, bedding and apparatus compliance (Jardine et al., 1984; Clayton \& Khatrush, 1986; Cuccovillo \& Coop, 1997). Global axial displacement was calculated from the axial actuator motor shaft encoder data. The change in the outer diameter of the specimen was measured using a linear variable differential transformer (LVDT) attached to a radial caliper. The change in the inner radius $r_{\mathrm{i}}$ was calculated from the change in the inner cell volume, assuming the specimen retained a cylindrical shape during deformation (Mamou, 2013). Global angular displacements were calculated from the torsional actuator shaft encoder data.

The axial force $F$ and the torque $T$ were measured using a combined load and torque cell located at the top of the specimen. The inner and outer cell pressures and the applied
Table 2. Clay contents, dry densities, water contents and void ratios of the investigated sand-clay mixes

\begin{tabular}{l|c|c|c|c}
\hline Test* & $\begin{array}{c}\text { Clay } \\
\text { content: } \%\end{array}$ & $\begin{array}{c}\text { Dry density: } \\
\mathrm{Mg} / \mathrm{m}^{3}\end{array}$ & $\begin{array}{c}\text { Water } \\
\text { content: } \%\end{array}$ & $\begin{array}{c}\text { Global } \\
\text { void ratio }\end{array}$ \\
\hline UA & 7 & $2 \cdot 15$ & $7 \cdot 88$ & $0 \cdot 23$ \\
UB & 11 & $2 \cdot 12$ & $8 \cdot 31$ & $0 \cdot 25$ \\
UC & 14 & $2 \cdot 12$ & $8 \cdot 47$ & $0 \cdot 25$ \\
FA & 7 & $2 \cdot 14$ & $7 \cdot 83$ & $0 \cdot 23$ \\
FB & 11 & $2 \cdot 12$ & $8 \cdot 39$ & $0 \cdot 25$ \\
FC & 14 & $2 \cdot 11$ & $8 \cdot 45$ & $0 \cdot 25$ \\
\hline
\end{tabular}

*The first letter of the test denotes undrained $(\mathrm{U})$ or free-to-drain $(\mathrm{F})$ conditions. The second letter denotes the material type (A, B or C).

back pressure were controlled and measured by global digital systems (GDS) pressure/volume controllers. Pore pressures were measured independently at the top and bottom of the specimen using Druck PDCR810 pressure transducers.

\section{Materials}

The materials tested replicated gradings used in the construction of foundations (sub-ballast layers) for the South African Coal Line. These provide a baseline material for which previous laboratory test and field performance data are available in the literature (Gräbe \& Clayton, 2009; Priest et al., 2010; Otter, 2011). The materials were represented by sand-clay mixes made up of varying proportions of Leighton Buzzard sand fractions B (LBSFB), C (LBSFC) and D (LBSFD); Hymod Prima clay (HPC); and Oakamoor HPF5 silica flour silt (Table 1).

Specimens were prepared by compaction to a target dry density of $2 \cdot 15 \mathrm{Mg} / \mathrm{m}^{3}$ to replicate compaction of the material in the field. Table 2 summarises the dry densities, water contents and global void ratios achieved.

\section{Test procedure}

Each specimen was saturated prior to testing, to avoid complications of internal drainage and pore air compression in globally undrained conditions. In reality the water content of the soil comprising a railway track foundation is likely to vary as a result of changes in weather, climate and groundwater conditions. In many parts of the world, unsaturated conditions may well be the norm; however, saturated conditions represent a likely worst case and a convenient reference benchmark, and hence were adopted in the tests reported in this paper. 


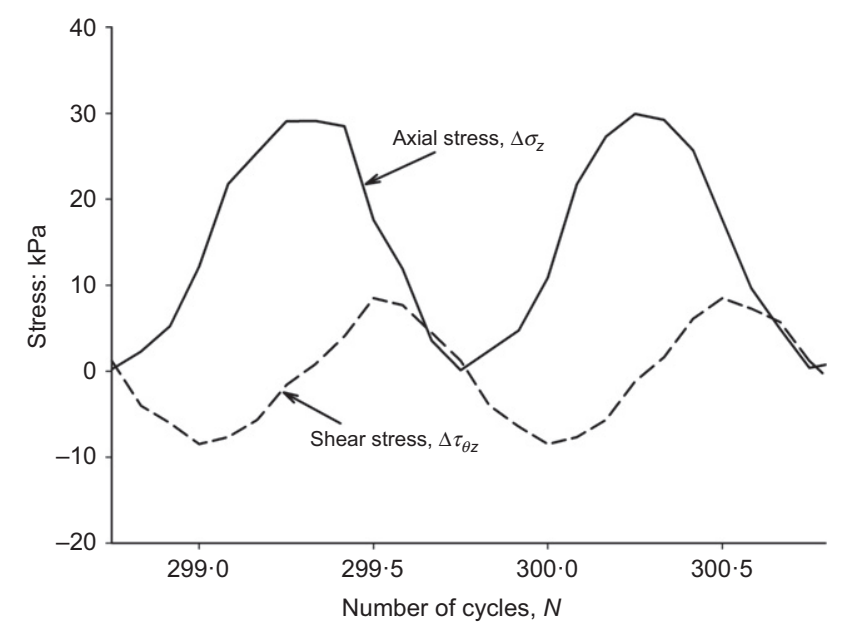

Fig. 1. Typical example of axial and shear stresses cycled $90^{\circ}$ out of phase

Specimens were flushed first with carbon dioxide $\left(\mathrm{CO}_{2}\right)$ to replace the air with a gas of greater solubility, and then with de-aired water. To dissolve any remaining gas, the back pressure was increased in stages together with the inner and outer cell pressures, so as to maintain a constant effective stress. On reaching a back pressure of at least $670 \mathrm{kPa}$, a period of time was allowed for any remaining gas to dissolve into the pore water. A final B-value in excess of 0.97 was taken to indicate a sufficient degree of saturation for a soil of relatively high stiffness (Black \& Lee, 1973).

To replicate the confining stresses typical of railway track foundations in the field, specimens were tested from an initial isotropic effective stress (cell pressure minus back pressure) of $33 \mathrm{kPa}$ (Gräbe, 2001). Each specimen was then subjected to cycles of axial stress of 0 to $30 \mathrm{kPa}$, together with cycles of shear stress of $\pm \Delta \tau_{\theta z}$, with a phase difference of $90^{\circ}$, as indicated in Fig. 1. The magnitude of the shear stress cycle $\Delta \tau_{\theta z}$, and hence the degree of PSR, were gradually increased, to explore a range of stress changes potentially associated with a railway track foundation.

The peak magnitude of the applied cyclic change in shear stress $\Delta \tau_{\theta z}$ was initially set to the value indicated by the numerical analyses presented by Powrie et al. (2007) for a soil element near the bottom of a railway track foundation extending to a depth of $1 \mathrm{~m}$ below the sleeper base $\left(\left|\Delta \tau_{\theta z}\right|=8.5 \mathrm{kPa}\right)$. Thereafter, the magnitude of the peak cyclic shear stress was incremented until failure occurred. As a point of reference, the cyclic shear stress calculated by the numerical analyses of Powrie et al. (2007) for a soil element at a depth of $0.3 \mathrm{~m}$ below the sleeper base (corresponding to the bottom of a standard $0.3 \mathrm{~m}$ thick layer of ballast) was $\left|\Delta \tau_{\theta z}\right| \sim 24 \mathrm{kPa}$.

Tests were carried out both under free-to-drain and undrained conditions. The objective of the undrained tests was to investigate the potential of the different sand-clay mixes to accumulate excess pore pressures, if unable to drain during load cycling. At the end of every undrained test stage and before the start of the next, specimens were allowed to drain so as to dissipate any accumulated excess pore pressure. The rest period varied depending on the clay content.

In the free-to-drain tests, the specimen was allowed to drain from the bottom during stress cycling. Pore pressures were measured at the top of the specimen, that is, the furthest point from the drainage boundary. No attempt was made to reduce the loading frequency to prevent the build-up of excess pore pressures, that is, to maintain fully drained conditions.
Free-to-drain tests investigated the susceptibility of the material to accelerated deterioration as a result of PSR, in conditions where the build-up or dissipation of any excess pore pressures was controlled by the consolidation characteristics of the soil (volumetric compressibility and permeability) and the drainage path length $d$ in relation to the frequency of loading $f$. The loading frequency used in the tests was $0.0083 \mathrm{~Hz}$ or approximately 30 cycles per hour. It is difficult to relate this directly and in general terms to field conditions. An intensively trafficked route might experience up to 24 trains per hour, with rest periods of 2-3 min in between. However, a fast train travelling at $50 \mathrm{~m} / \mathrm{s}$ would give bursts of axle loading at $8 \mathrm{~Hz}$ (which would be felt at a depth of $\sim 0.3 \mathrm{~m}$ below the sleeper base), or bogie loading at $4 \mathrm{~Hz}$ (which would be felt at a depth of about $1 \mathrm{~m}$ below the sleeper base; Powrie et al. (2007)), during each train passage.

The maximum drainage path length in the laboratory tests was $200 \mathrm{~mm}$. Equality of the dimensionless group $c_{\mathrm{v}} / f d^{2}$ for the same consolidation coefficient $c_{\mathrm{v}}$ between the laboratory and the field would suggest an equivalent train frequency of 13 per hour for a maximum field drainage path length of $0.3 \mathrm{~m}$. It is considered that the free-to-drain tests probably represent a best-case field scenario, in that in reality the relevant frequency of loading (whether in terms of trains per hour or axles/bogies per second) would be higher and the maximum drainage path longer, so there would be less opportunity for excess pore water pressures to dissipate.

A summary of the stress cycles applied in all of the PSR tests carried out in this research is given in Table 3. The first letter identifies the drainage condition; $U$ for undrained and $\mathrm{F}$ for free-to-drain tests. The second letter denotes the type of material (A, B or $\mathrm{C}$ ); the number that follows is the magnitude of cyclic shear stress imposed on the specimen. Before each undrained test, the specimen was subjected to a free-to-drain cyclic PSR preloading stage to reduce the effects of specimen preparation on the subsequent results. The free-to-drain preloading stages of undrained tests are denoted by the letter P.

\section{RESULTS AND DISCUSSION}

Axial strain accumulation

The accumulation of permanent strain with the number of cycles of increasing cyclic shear stress is illustrated in Figs 2, 3 and 4 for materials A, B and C, respectively. The different test stages (i.e. the different magnitudes of cyclic shear stress) are indicated by the letters (a) to (h). For materials B and C (Figs 3 and 4), in both undrained and free-to-drain conditions, there is a threshold cyclic shear stress beyond which the rate of increase in the plastic strain during each cycle accelerates, resulting in what might be described as fatigue failure as a result of the repeated loading (for example at stage $(\mathrm{g})$ in Fig. 3 for the free-to-drain test). Below this cyclic shear stress threshold, the response of the specimens was stable over a large number of loading cycles with no unrestrained accumulation of axial strain (for example, stage (a) in Fig. 3 for the undrained test). Material A exhibited a cyclic shear stress threshold in free-to-drain conditions (stage (f), Fig. 2). When tested undrained, material $\mathrm{A}$ failed at the lowest cyclic shear stress applied $\left(\left|\Delta \tau_{\theta z}\right|=8.5 \mathrm{kPa}\right)$, suggesting that the cyclic shear stress threshold in undrained conditions was equal to or less than this value (stage (a), Fig. 2).

Previous strain-controlled experiments on clayey sands in undrained cyclic triaxial loading conditions have yielded similar observations in terms of a threshold strain, below which strain cycling results in stable behaviour, and above which strains (and pore pressures) accumulate with increasing number of loading cycles (Georgiannou et al., 1991). 
Table 3. Summary of the testing programme and key results

(a) Undrained tests

Cyclic preloading stages (free to drain)

\begin{tabular}{|c|c|c|c|}
\hline Test & $\begin{array}{l}\text { Material type } \\
\text { (clay content) }\end{array}$ & $\Delta \tau_{\theta z}$ & Number of cycles \\
\hline $\begin{array}{l}\text { FA } 8 \cdot 5 \mathrm{P} \\
\text { FA } 11 \cdot 5 \mathrm{P} \\
\text { FB } 8 \cdot 5 \mathrm{P} \\
\text { FB } 11 \cdot 5 \mathrm{P} \\
\text { FC } 8 \cdot 5 \mathrm{P} \\
\text { FC } 11 \cdot 5 \mathrm{P}\end{array}$ & $\begin{array}{l}\text { A }(7 \%) \\
\text { B }(11 \%)\end{array}$ & $\begin{array}{l}\Delta \tau_{\theta z}=+8.5 \rightarrow-8.5 \mathrm{kPa} \\
\Delta \tau_{\theta z}=+11.5 \rightarrow-11.5 \mathrm{kPa} \\
\Delta \tau_{\theta z}=+8.5 \rightarrow-8.5 \mathrm{kPa} \\
\Delta \tau_{\theta z}=+11.5 \rightarrow-11.5 \mathrm{kPa} \\
\Delta \tau_{\theta z}=+8.5 \rightarrow-8.5 \mathrm{kPa} \\
\Delta \tau_{\theta z}=+11.5 \rightarrow-11.5 \mathrm{kPa}\end{array}$ & $\begin{array}{l}710 \\
710 \\
708 \\
700 \\
712 \\
710\end{array}$ \\
\hline
\end{tabular}

Undrained stages

\begin{tabular}{|c|c|c|c|c|c|c|}
\hline Test & Test stage & $\begin{array}{l}\text { Material type } \\
\text { (clay content) }\end{array}$ & $\Delta \tau_{\theta z}$ & $\begin{array}{l}\text { Number } \\
\text { of cycles }\end{array}$ & $\begin{array}{c}\text { Resilient } \\
\text { modulus*: } \mathrm{MPa}\end{array}$ & $\begin{array}{l}\text { Cyclic shear stress } \\
\text { threshold: } \mathrm{kPa}\end{array}$ \\
\hline UA $8 \cdot 5$ & a & A $(7 \%)$ & $\Delta \tau_{\theta z}=+8.5 \rightarrow-8.5 \mathrm{kPa}$ & 729 & 58 & $\leq 8 \cdot 5$ \\
\hline UB8.5 & a & $\mathrm{B}(11 \%)$ & $\Delta \tau_{\theta z}=+8.5 \rightarrow-8.5 \mathrm{kPa}$ & $710 \dagger$ & 87 & $11 \cdot 5$ \\
\hline $\mathrm{UB} 11 \cdot 5$ & $\mathrm{~b}$ & & $\Delta \tau_{\theta z}=+11.5 \rightarrow-11.5 \mathrm{kPa}$ & 321 & 61 & \\
\hline $\mathrm{UC} 8 \cdot 5$ & $\mathrm{a}$ & $\mathrm{C}(14 \%)$ & $\Delta \tau_{\theta z}=+8.5 \rightarrow-8.5 \mathrm{kPa}$ & 710 & 101 & $14 \cdot 5$ \\
\hline $\mathrm{UC} 11 \cdot 5$ & $\mathrm{~b}$ & & $\Delta \tau_{\theta z}=+11.5 \rightarrow-11.5 \mathrm{kPa}$ & 710 & 104 & \\
\hline $\mathrm{UC} 14 \cdot 5$ & $\mathrm{c}$ & & $\Delta \tau_{\theta z}=+14.5 \rightarrow-14.5 \mathrm{kPa}$ & 345 & 73 & \\
\hline
\end{tabular}

(b) Free-to-drain tests

\begin{tabular}{|c|c|c|c|c|c|c|}
\hline Test & Test stage & B & $\Delta \tau_{\theta z}$ & $\begin{array}{l}\text { Number } \\
\text { of cycles }\end{array}$ & Resilient modulus: $\mathrm{MPa}$ & Cyclic shear stress threshold: $\mathrm{kPa}$ \\
\hline FA $8 \cdot 5$ & a & A $(7 \%)$ & $\Delta \tau_{\theta z}=+8.5 \rightarrow-8.5 \mathrm{kPa}$ & 720 & 86 & \\
\hline FA $11 \cdot 5$ & $\mathrm{~b}$ & & $\Delta \tau_{\theta z}=+11.5 \rightarrow-11.5 \mathrm{kPa}$ & 718 & 93 & \\
\hline FA14.5 & $\mathrm{c}$ & & $\Delta \tau_{\theta z}=+14.5 \rightarrow-14.5 \mathrm{kPa}$ & 720 & 92 & \\
\hline FA17.5 & $\mathrm{d}$ & & $\Delta \tau_{\theta z}=+17.5 \rightarrow-17.5 \mathrm{kPa}$ & 721 & 97 & \\
\hline FA $20 \cdot 5$ & $\mathrm{e}$ & & $\Delta \tau_{\theta z}=+20.5 \rightarrow-20.5 \mathrm{kPa}$ & 703 & 96 & \\
\hline FA23.5 & $\mathrm{f}$ & & $\Delta \tau_{\theta z}=+23 \cdot 5 \rightarrow-23.5 \mathrm{kPa}$ & 103 & 80 & $23 \cdot 5$ \\
\hline FB $8 \cdot 5$ & $\mathrm{a}$ & B $(11 \%)$ & $\Delta \tau_{\theta z}=+8.5 \rightarrow-8.5 \mathrm{kPa}$ & 705 & 75 & \\
\hline FB11.5 & $\mathrm{b}$ & & $\Delta \tau_{\theta z}=+11.5 \rightarrow-11.5 \mathrm{kPa}$ & 715 & 87 & \\
\hline FB14.5 & $\mathrm{c}$ & & $\Delta \tau_{\theta z}=+14.5 \rightarrow-14.5 \mathrm{kPa}$ & 721 & 91 & \\
\hline FB17.5 & $\mathrm{d}$ & & $\Delta \tau_{\theta z}=+17.5 \rightarrow-17.5 \mathrm{kPa}$ & 708 & 95 & \\
\hline FB20.5 & $\mathrm{e}$ & & $\Delta \tau_{\theta z}=+20.5 \rightarrow-20.5 \mathrm{kPa}$ & 707 & 100 & \\
\hline FB23.5 & $\mathrm{f}$ & & $\Delta \tau_{\theta z}=+23.5 \rightarrow-23.5 \mathrm{kPa}$ & 713 & 102 & \\
\hline FB26.5 & $\mathrm{g}$ & & $\Delta \tau_{\theta z}=+26 \cdot 5 \rightarrow-26.5 \mathrm{kPa}$ & 57 & 87 & $26 \cdot 5$ \\
\hline FC $8 \cdot 5$ & a & $\mathrm{C}(14 \%)$ & $\Delta \tau_{\theta z}=+8.5 \rightarrow-8.5 \mathrm{kPa}$ & 722 & 89 & \\
\hline FC11.5 & $\mathrm{b}$ & & $\Delta \tau_{\theta z}=+11.5 \rightarrow-11.5 \mathrm{kPa}$ & 720 & 95 & \\
\hline FC14.5 & $\mathrm{c}$ & & $\Delta \tau_{\theta z}=+14.5 \rightarrow-14.5 \mathrm{kPa}$ & 720 & 97 & \\
\hline $\mathrm{FC} 17 \cdot 5$ & $\mathrm{~d}$ & & $\Delta \tau_{\theta z}=+17.5 \rightarrow-17.5 \mathrm{kPa}$ & 727 & 98 & \\
\hline $\mathrm{FC} 20 \cdot 5$ & $\mathrm{e}$ & & $\Delta \tau_{\theta z}=+20 \cdot 5 \rightarrow-20 \cdot 5 \mathrm{kPa}$ & 721 & 103 & \\
\hline $\mathrm{FC} 23 \cdot 5$ & $\mathrm{f}$ & & $\Delta \tau_{\theta z}=+23.5 \rightarrow-23.5 \mathrm{kPa}$ & 720 & 105 & \\
\hline $\mathrm{FC} 26 \cdot 5$ & $\mathrm{~g}$ & & $\Delta \tau_{\theta z}=+26.5 \rightarrow-26.5 \mathrm{kPa}$ & 716 & 109 & \\
\hline $\mathrm{FC} 29 \cdot 5$ & $\mathrm{~h}$ & & $\Delta \tau_{\theta z}=+29 \cdot 5 \rightarrow-29 \cdot 5 \mathrm{kPa}$ & 306 & 72 & $29 \cdot 5$ \\
\hline
\end{tabular}

* Measured at the end of each test stage.

$\dagger$ Halfway through UB8.5P, owing to a fault in the control system, the axial stress $\Delta \sigma_{\mathrm{z}}$ remained constant and equal to $15 \mathrm{kPa}$ rather than being cycled between 0 and $30 \mathrm{kPa}$, while the shear stress continued to be cycled between the desired values.

Within the range of materials investigated in this research

(a) undrained conditions were much more onerous than those in which drainage was able to occur (i.e. the cyclic shear stress threshold was much smaller in undrained conditions)

(b) the magnitude of the cyclic shear stress threshold in given conditions (i.e. undrained or free to drain) increased with increasing clay content.

In free-to-drain conditions, where the rate of pore pressure dissipation was regulated by the permeability and the volumetric compressibility of the soil and the drainage path length, materials B and C (containing moderate amounts of fines) remained at least marginally stable over the range of increase in cyclic shear stress (stages (a) to (f), Fig. 3 and stages (a) to (g), Fig. 4) expected to occur at depths greater than about $0.3 \mathrm{~m}$ in the field (a typical minimum depth of ballast below sleeper soffit level on a ballasted railway track). Material A, however, failed when a cyclic shear stress of $\left|\Delta \tau_{\theta z}\right|=23.5 \mathrm{kPa}$ (stage (f), Fig. 2) was applied and suffered large strains at $\left|\Delta \tau_{\theta z}\right|=20 \cdot 5 \mathrm{kPa}$ (stage (e), Fig. 2).

All of the materials tested appeared to be very sensitive to small changes in the extent of PSR once the cyclic strain threshold was exceeded, and the transition from stable behaviour to fatigue failure could be sudden. This implies that a currently stable railway track foundation will not necessarily be able to accommodate heavier traffic loads.

In undrained conditions, none of the materials in Figs 2-4 would be suitable for use within a depth of about $1 \mathrm{~m}$ below 


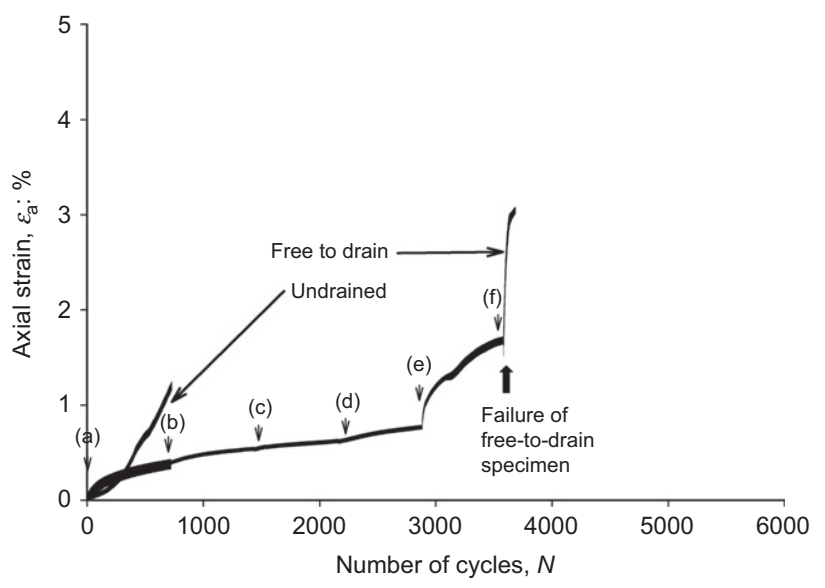

Fig. 2. Axial strain accumulation during undrained and free-to-drain cyclic stress increases for material A (7\% clay)

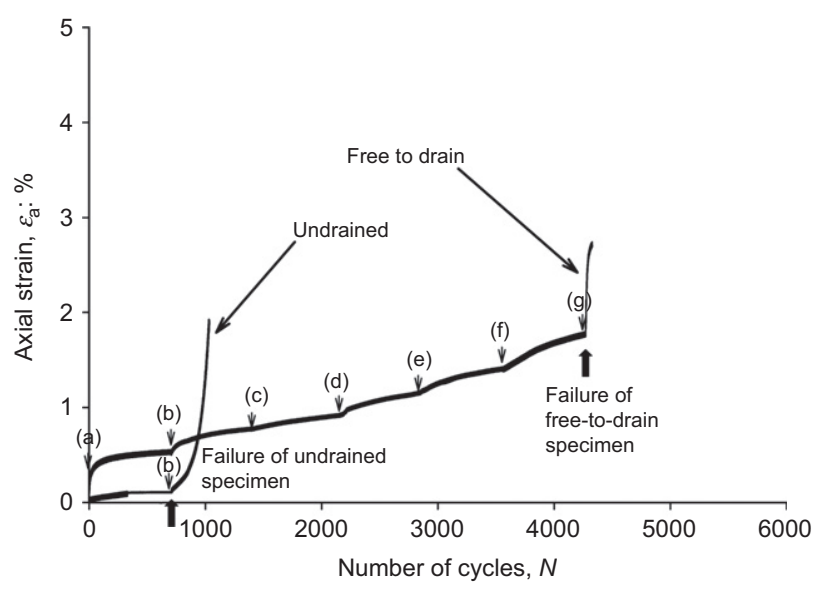

Fig. 3. Axial strain accumulation during undrained and free-to-drain cyclic stress increases for material B ( $11 \%$ clay)

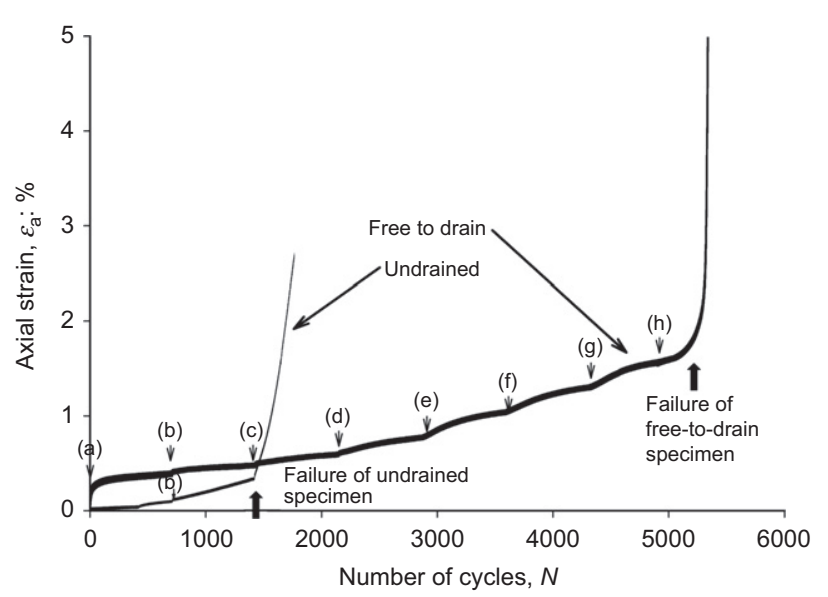

Fig. 4. Axial strain accumulation during undrained and free-to-drain cyclic stress increases for material C $(14 \%$ clay $)$

the sleeper base, with material A failing at the lowest level of cyclic shear stress $\left(\left|\Delta \tau_{\theta z}\right|=8.5 \mathrm{kPa}\right)$ considered.

\section{Excess pore pressure and volumetric strains}

The excess pore pressures generated during both undrained and free-to-drain tests are shown in Figs 5, 6 and 7 for materials $\mathrm{A}, \mathrm{B}$ and $\mathrm{C}$, respectively. The generation of significant excess pore pressures was always associated

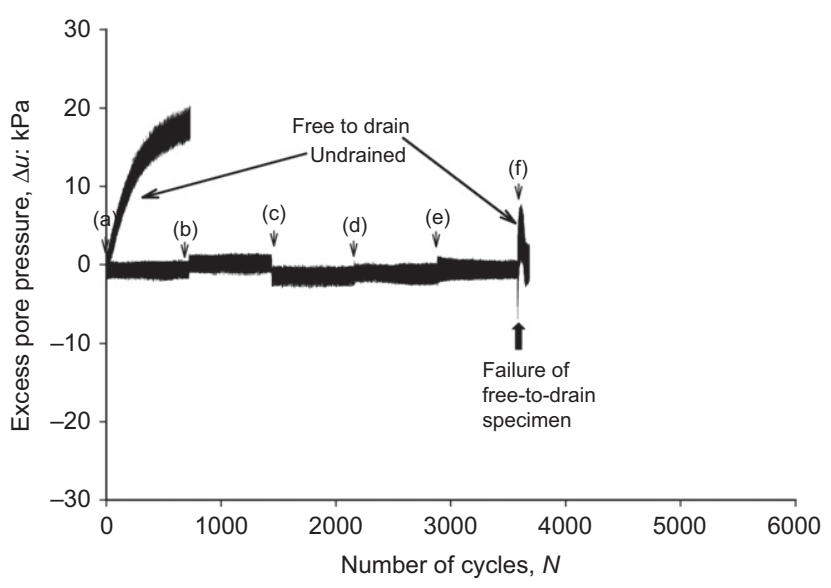

Fig. 5. Pore pressure changes during undrained and free-to-drain cyclic stress increases for material A (7\% clay)

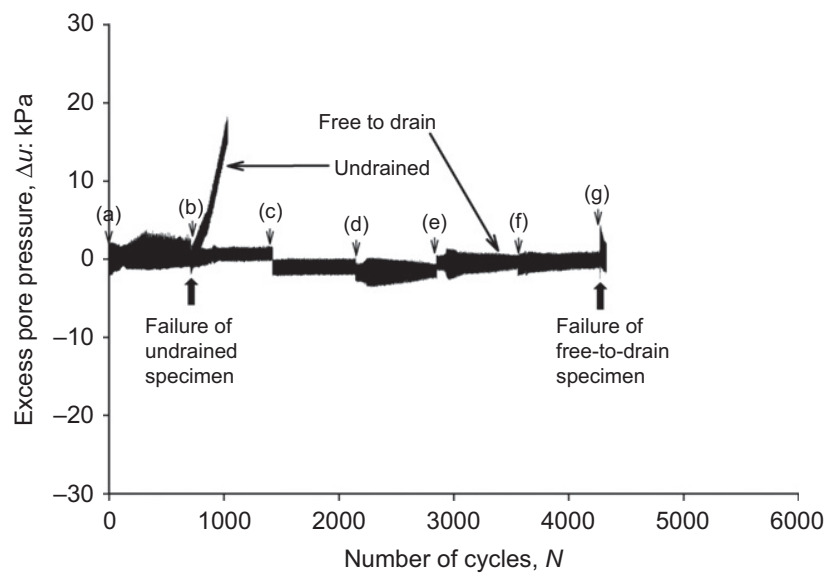

Fig. 6. Pore pressure changes during undrained and free-to-drain cyclic stress increases for material B (11\% clay)

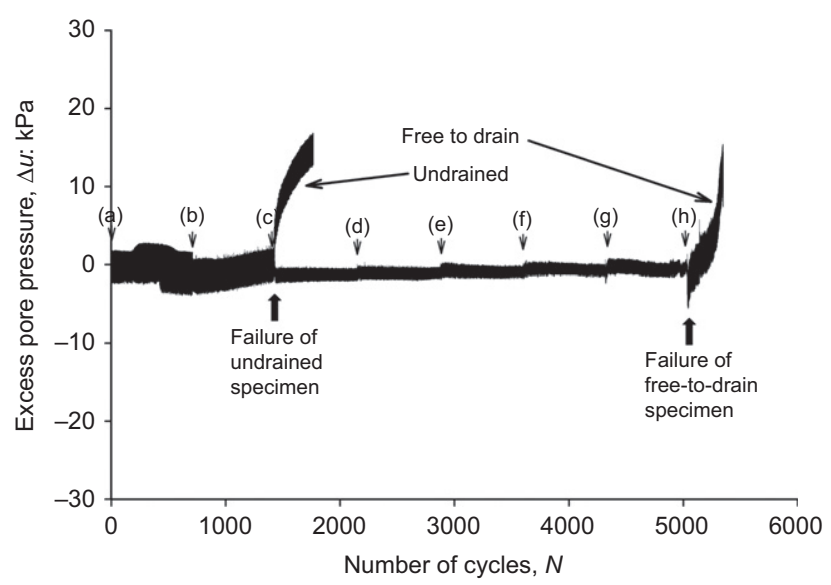

Fig. 7. Pore pressure changes during undrained and free-to-drain cyclic stress increases for material C (14\% clay)

with the cyclic shear stress threshold being exceeded, in both undrained (stage (b), Fig. 6 and stage (c), Fig. 7) and free-to-drain conditions (stage (f), Fig. 5, stage (g), Fig. 6 and stage (h), Fig. 7). In principle, the maximum pore pressures generated should depend on the loading applied and whether the material yielded or remained elastic, while the degree of dissipation should depend on the permeability, stiffness, rest period and drainage path length, in accordance with conventional consolidation theory. 
Prevention of drainage in the undrained tests led to the build-up of pore pressures that were unable to dissipate at generally lower magnitudes of cyclic shear stress, and contributed to the rapid failure of specimens as shown in Fig. 7, stage (c). The free-to-drain test specimens failed when the pore pressures generated became too large to dissipate between successive peak loads (for example stage (h), Fig. 7).

Graphs of volumetric strain against number of cycles for the free-to-drain tests are shown in Figs 8, 9 and 10 for

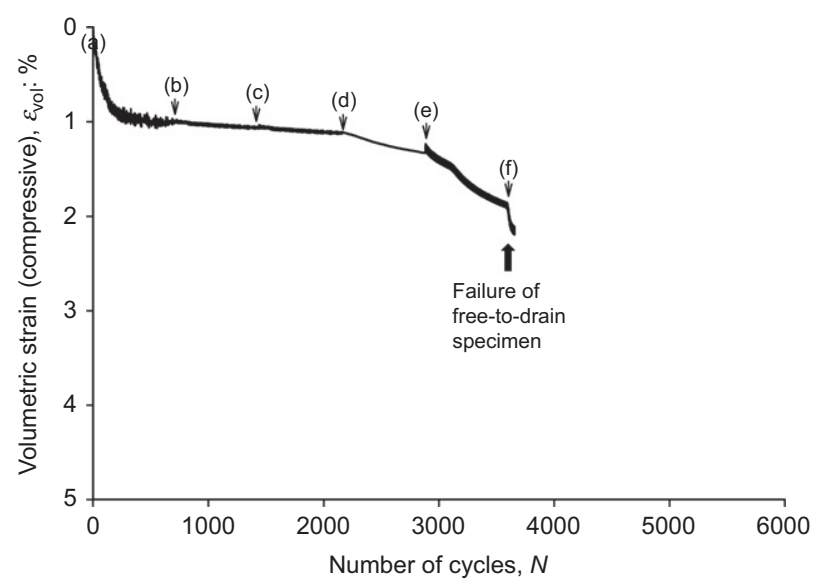

Fig. 8. Compressive volumetric strain accumulation during free-todrain cyclic stress increases for material A ( $7 \%$ clay)

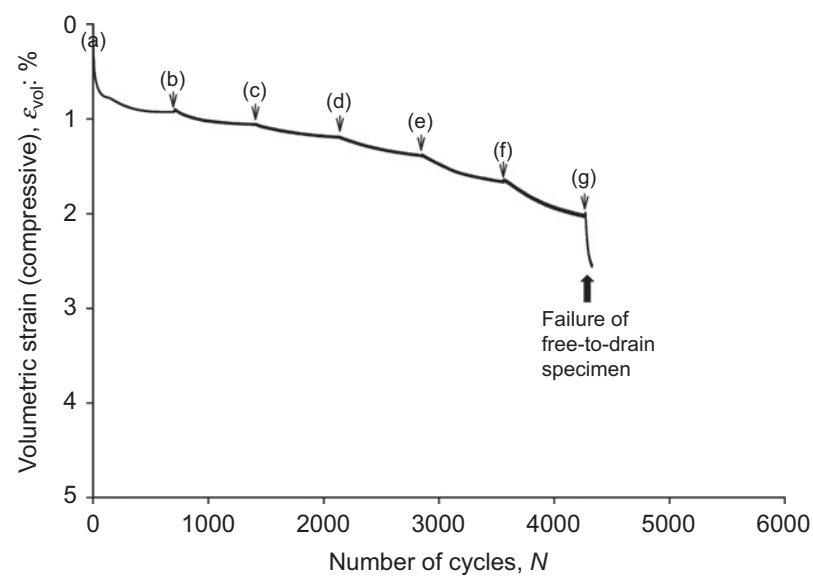

Fig. 9. Compressive volumetric strain accumulation during free-todrain cyclic stress increases for material B (11\% clay)

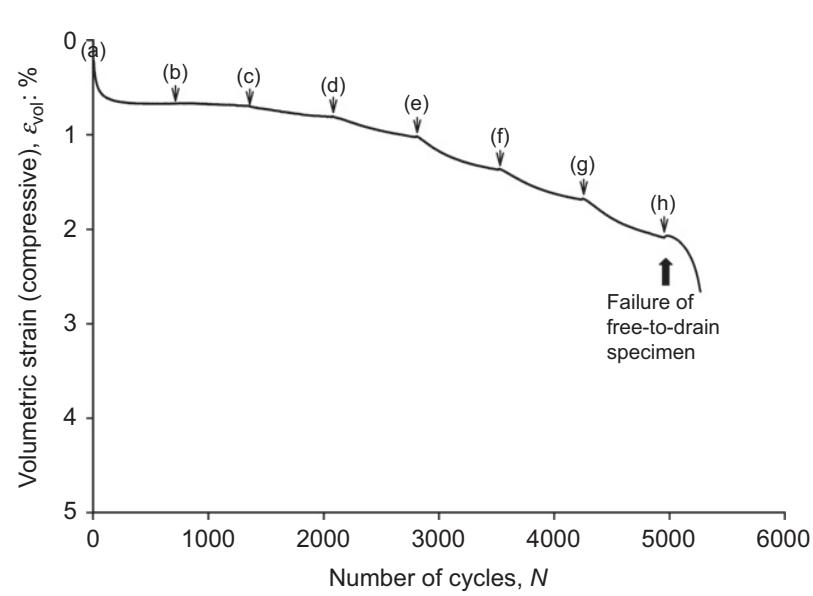

Fig. 10. Compressive volumetric strain accumulation during free-todrain cyclic stress increases for material C (14\% clay) materials $\mathrm{A}, \mathrm{B}$ and $\mathrm{C}$ respectively. Volumetric strains were always compressive, and mirrored the axial strain behaviour in that they were generally reasonably stable within a given magnitude of cyclic shear stress until the cyclic shear stress threshold was reached. At this point, much larger volumetric strains started to develop with continued cycles of shear stress. The volumetric compressibility of material A was similar to that of material $\mathrm{B}$, while material C (14\% clay) was volumetrically slightly stiffer.

Increasing the clay content resulted in the development of smaller pore pressures under any given set of stress and drainage conditions (for example stage (f) in Figs 5-7). Although increasing the clay content of the mix would be expected to reduce the permeability and hence inhibit the dissipation of excess pore pressures between successive load peaks, the data suggest that the dominant (and beneficial) effect was an accompanying increase in volumetric stability (if not stiffness), which is possibly a result of the wider range of grain sizes in the mix.

\section{Resilient modulus}

The changes in resilient modulus with the number of stress cycles are shown for undrained conditions in Figs 11-13, and for free-to-drain conditions in Figs 14-16, for materials A to C. For a given magnitude of cyclic shear stress in undrained conditions, the resilient modulus typically remained reasonably steady until the cyclic shear stress threshold was reached,

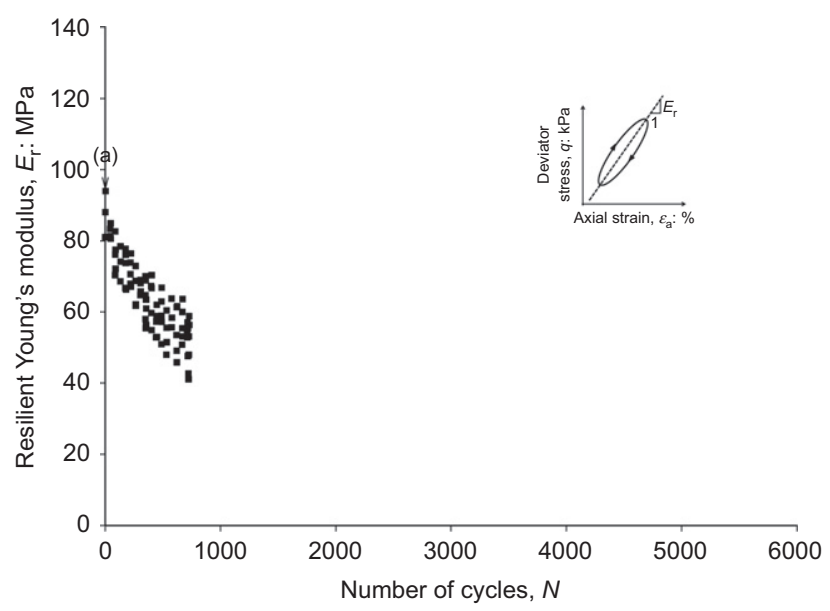

Fig. 11. Change in resilient Young's modulus during undrained cyclic stress increases for material A ( $7 \%$ clay)

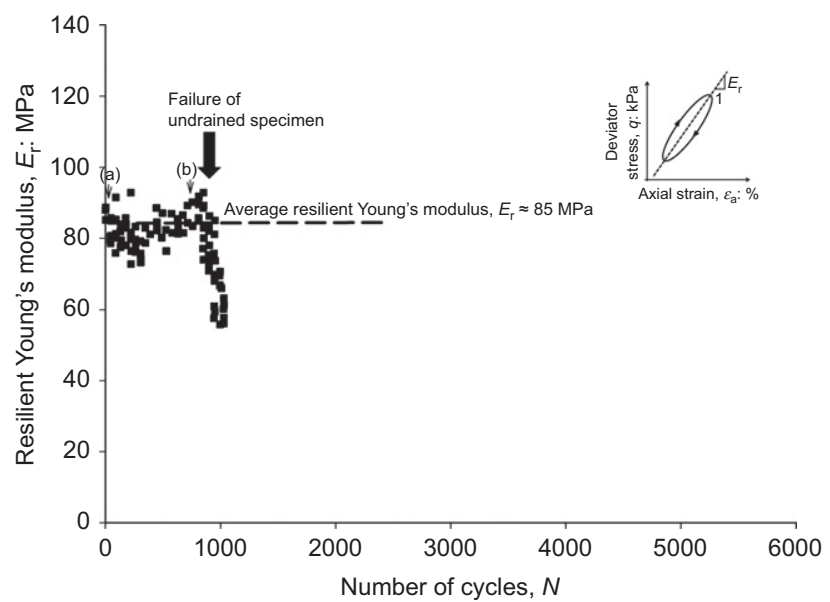

Fig. 12. Change in resilient modulus during undrained cyclic stress increases for material B ( $11 \%$ clay) 
at which point it started to reduce rapidly (stage (b), Fig. 12 and stage (c), Fig. 13). However, material $A$ failed at the lowest level of cyclic shear stress $\left(\Delta \tau_{\theta z}=8.5 \mathrm{kPa}\right)$ and therefore showed a continuous decrease in resilient modulus from the outset (stage (a), Fig. 11).

In free-to-drain conditions the resilient modulus increased with the number of cycles and increasing cyclic shear stress magnitude until the cyclic shear stress threshold was reached, when again a rapid degradation in resilient modulus occurred (stage (f), Fig. 14, stage (g), Fig. 15 and stage (h), Fig. 16).

These data suggest that below the cyclic shear stress threshold, changes in the amount of in-cycle PSR will have little effect on the resilient modulus of the foundation and, depending on the drainage conditions, may even increase it (for example stages (a) to (b), Fig. 13 and stages (a) to (g), Fig. 16). This implies that the response of a railway track foundation to cyclic shear stresses only becomes critical when the cyclic threshold stress of the soil is exceeded. However, deterioration may then be rapid and its onset may occur with little or no warning in terms of prior stiffness change (e.g. stage (f), Fig. 10, although plastic strains had started to accumulate at stage (e) in this case).

Figure 17 shows stress paths in terms of deviator stress $q$, defined in the conventional way as

$$
q=\frac{1}{\sqrt{2}} \sqrt{\left(\sigma_{1}^{\prime}-\sigma_{2}^{\prime}\right)^{2}+\left(\sigma_{1}^{\prime}-\sigma_{3}^{\prime}\right)^{2}+\left(\sigma_{2}^{\prime}-\sigma_{3}^{\prime}\right)^{2}}
$$

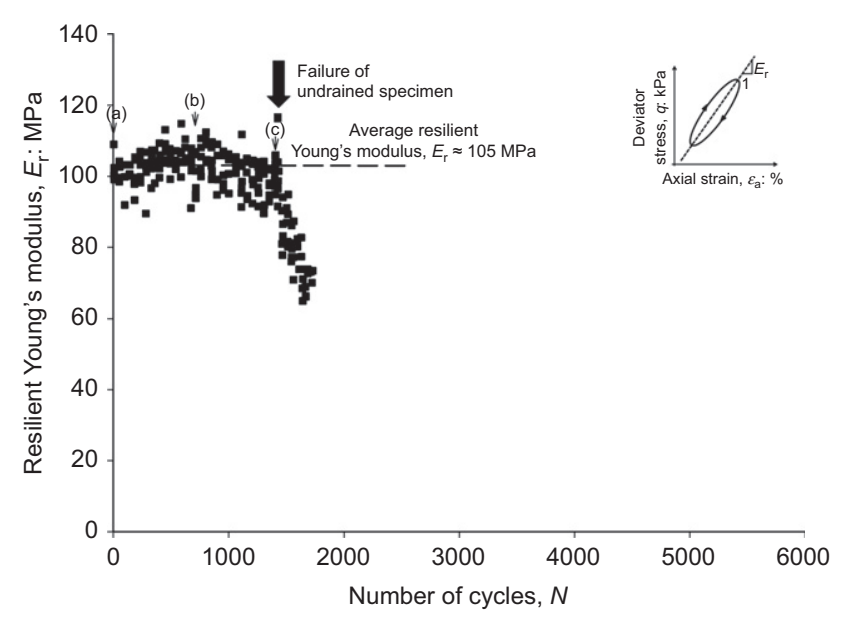

Fig. 13. Change in resilient Young's modulus during undrained cyclic stress increases for material C (14\% clay)

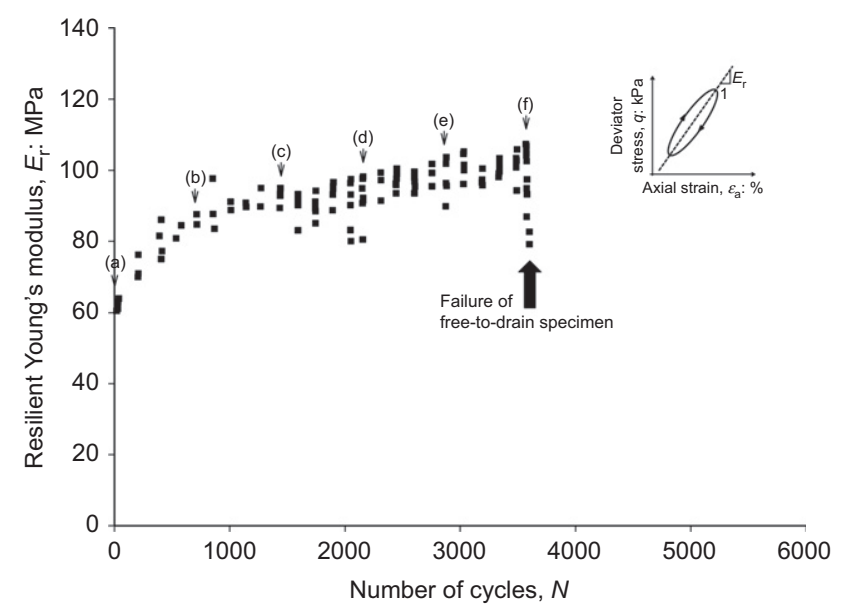

Fig. 14. Change in resilient Young's modulus during free-to-drain cyclic stress increases for material A (7\% clay) against mean effective stress $p^{\prime}$ for the undrained test stages on materials $\mathrm{A}, \mathrm{B}$ and $\mathrm{C}$ that caused failure (test stages $\mathrm{UA} 8 \cdot 5$, UB11.5 and $\mathrm{UC} 14 \cdot 5$, respectively). The move towards the critical stress ratio (as identified by Gräbe \& Clayton (2009)) with increasing number of load cycles as pore pressures build up is apparent.

Practical implications for the design of railway track foundations

The effect of increasing the clay content on the cyclic stress threshold of the mixes is illustrated for both undrained and free-to-drain conditions in Fig. 18. Increasing the clay content from $7 \%$, through $11 \%$ to $14 \%$, increased the cyclic shear stress threshold of the mix in both undrained and free-to-drain conditions. The cyclic shear stress threshold was greater in free-to-drain conditions than undrained.

The right-hand scale on Fig. 18 indicates the equivalent depth below sleeper base level at which the cyclic stress on the left-hand scale is reached, according to the finite-element analyses presented by Powrie et al. (2007). For a foundation material to perform acceptably, there would need to be an adequate margin between the cyclic shear stress threshold and the cyclic stress imposed at the depth at which the material was to be used.

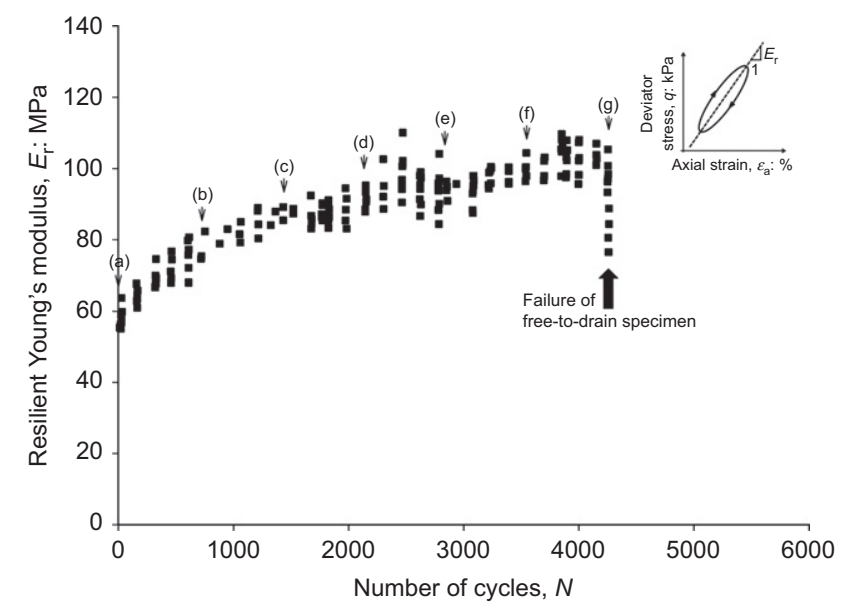

Fig. 15. Change in resilient Young's modulus during free-to-drain cyclic stress increases for material B (11\% clay)

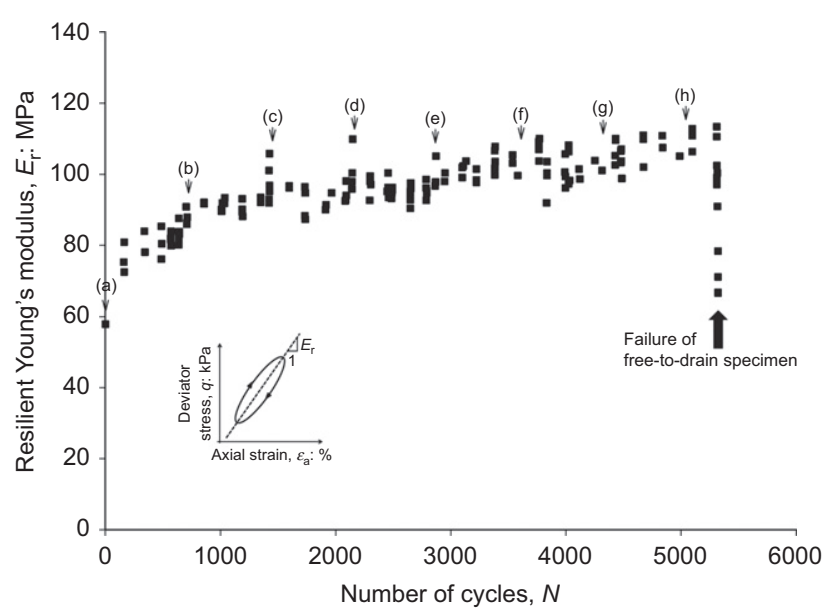

Fig. 16. Change in resilient Young's modulus during free-to-drain cyclic stress increases for material C (14\% clay) 
In undrained conditions, all of the materials tested are acceptable for use at depths greater than $1 \mathrm{~m}$ below the sleeper base. Drainage reduces the minimum depth at which a material will remain below the cyclic threshold stress; subject to the applicability of the drainage conditions in the laboratory tests to a given field situation, materials with a clay content of more than about $10 \%$ may be suitable for use

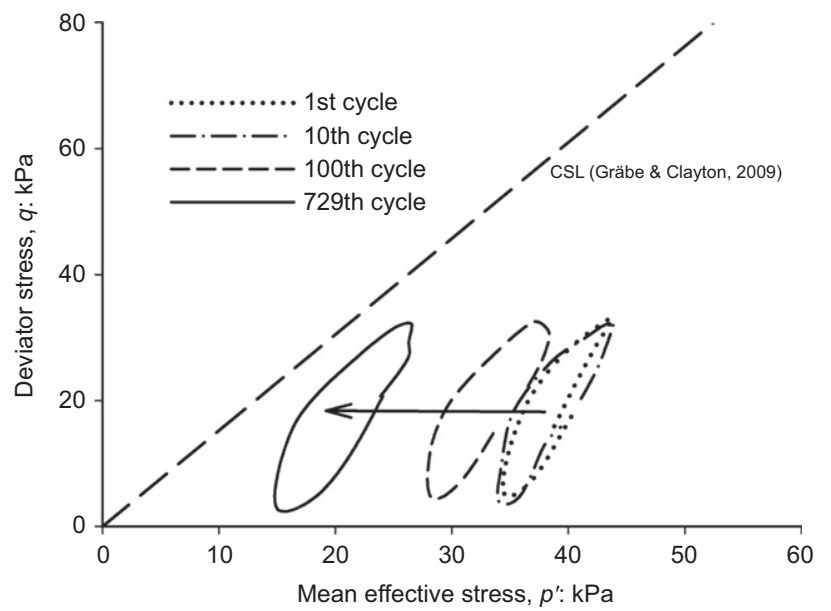

(a)

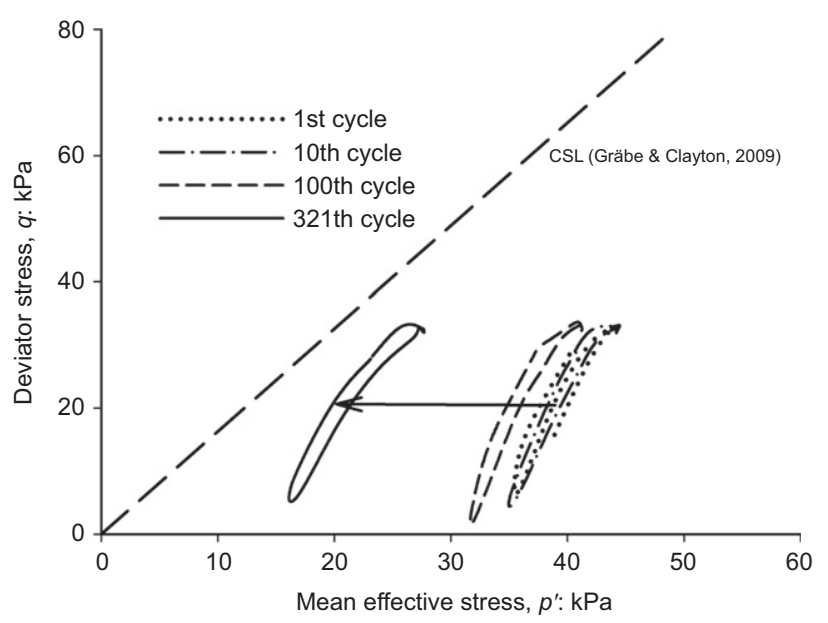

(b)

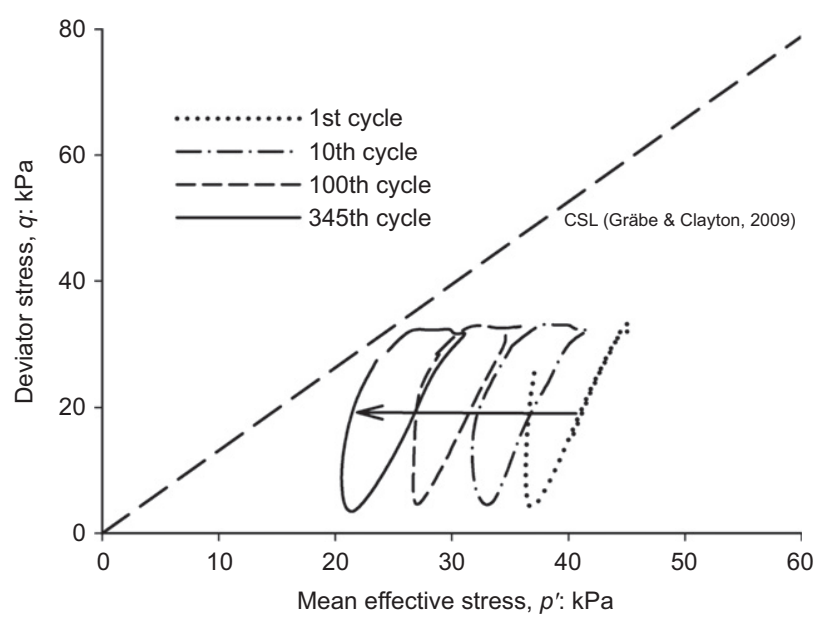

(c)

Fig. 17. Stress paths followed by materials $\mathrm{A}, \mathrm{B}$ and $\mathrm{C}$ at failure (test stages UA8 5 , UB11.5 and UC14.5, respectively): (a) material A ( $7 \%$ clay); (b) material B (11\% clay); (c) material C (14\% clay) (CSL, critical state line) immediately below the ballast (a depth of $0.3 \mathrm{~m}$ below the sleeper base).

Figures 19 and 20 summarise how the resilient modulus varies with clay content and the magnitude of the shear strain cycle in undrained and free-to-drain conditions. Below the cyclic shear stress threshold, the resilient stiffness tended to

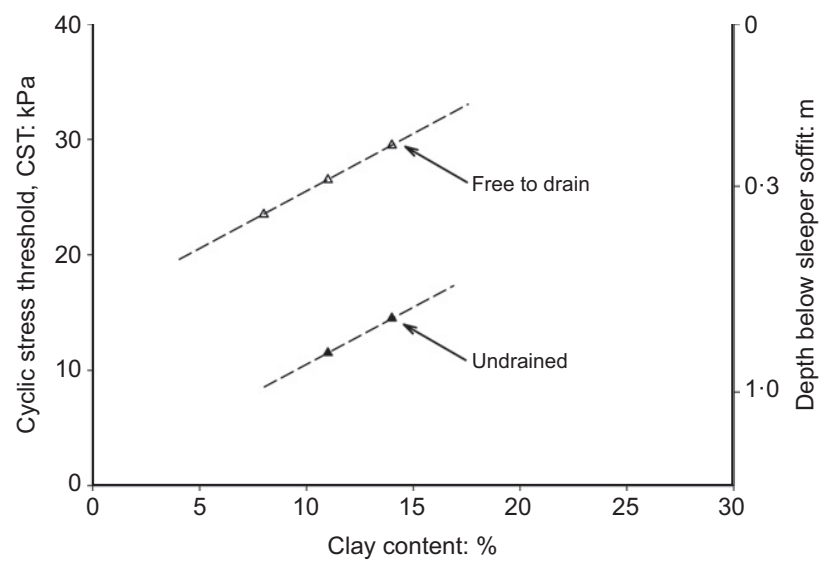

Fig. 18. Effect of increasing the clay content on the cyclic shear stress threshold of the mixes in undrained and free-to-drain conditions

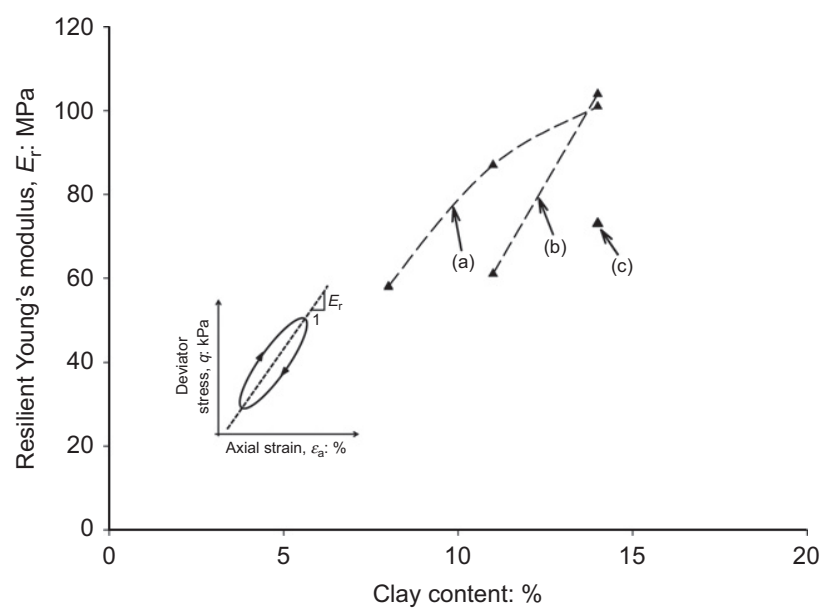

Fig. 19. Variation in the resilient Young's modulus with clay content and magnitude of shear strain cycle in undrained conditions

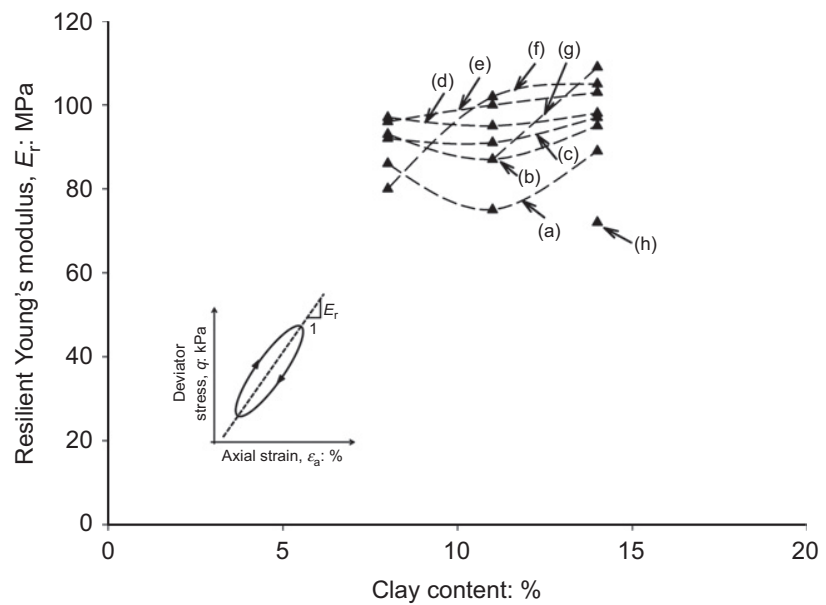

Fig. 20. Variation in the resilient Young's modulus with clay content and magnitude of shear strain cycle in free-to-drain conditions 
equalise with increasing magnitude of cyclic shear stress over the range of clay contents investigated (for example Fig. 20, stages (b) to (f)) for 7\%, 11\% and 14\% clay). The influence of the clay content on the resilient modulus for a given magnitude of applied shear stress became more significant once the cyclic stress threshold was exceeded (for example Fig. 19, stage (b) for $11 \%$ and 14\% clay); this is inescapable given the dependence of cyclic shear stress threshold on clay content. However, as long as the cyclic stress threshold of the mix is not exceeded, varying the clay content between $7 \%$ and $14 \%$ should have only a secondorder effect on the resilient modulus over the lifetime of a railway track foundation.

\section{CONCLUSIONS}

(a) The ability of the soil within a railway track foundation to respond resiliently, without the development of excessive plastic settlements, depends on the magnitude of the cyclic shear stress applied by train loading remaining below a certain threshold value.

(b) Below the cyclic shear stress threshold, the response of soils containing a range of sand, silt and clay materials was stable over a large number of loading cycles. In undrained conditions, cyclic changes in shear stress below the threshold value had no significant effect on the resilient stiffness of the soils tested. In free-to-drain conditions, the resilient stiffness increased with number of cycles and with increasing shear stress below the threshold level.

(c) Once the cyclic shear stress threshold was exceeded, a rapid reduction in stiffness and stability ensued. The soils tested were sensitive to even small changes in the magnitude of cyclic shear stress near the cyclic shear stress threshold. Small increases in cyclic shear stress could trigger the rapid deterioration of a previously stable sand-clay mix. The fact that a railway track foundation is currently stable may therefore not be a reliable indicator of its ability to accommodate significantly heavier traffic.

(d) The deterioration in resilient modulus and material stability was generally associated with the generation of large excess pore water pressures, even in free-to-drain conditions in which there had been no significant excess pore pressure generation at lower cyclic shear stresses. In free-to-drain conditions, instability was associated with the development of substantially increased compressive volumetric strains.

(e) The cyclic shear stress threshold in both undrained and free-to-drain conditions increased as the clay content of the soil was increased from $7 \%$ to $14 \%$. Increasing the clay content also reduced the excess pore pressure generation in both undrained and free-to-drain conditions. The cyclic shear stress threshold reduced dramatically when specimen drainage was prevented. Thus internal or external drainage is likely to play an important role in the continuing stability of railway foundations in the field.

( $f$ ) For the materials tested, the cyclic shear stress threshold in free-to-drain conditions was generally similar to or less than the cyclic shear stress in the soil immediately below a $0.3 \mathrm{~m}$ deep ballast bed, but comfortably greater than the cyclic shear stress at a depth of $1 \mathrm{~m}$ below the sleeper base. In undrained conditions, the cyclic shear stress threshold was generally similar to the likely cyclic shear stress at a depth of $1 \mathrm{~m}$ below the sleeper base. These factors would need to be taken into account in assessing the suitability of a natural or engineered railway track foundation material, either within the sub-ballast zone (a depth of $0.3 \mathrm{~m}$ to $1.0 \mathrm{~m}$ below the sleeper base) or below it.

\section{ACKNOWLEDGEMENT}

The research was carried out with the financial support of the Engineering and Physical Sciences Research Council (grant number EP/H044949/1, Railway Track for the 21st Century).

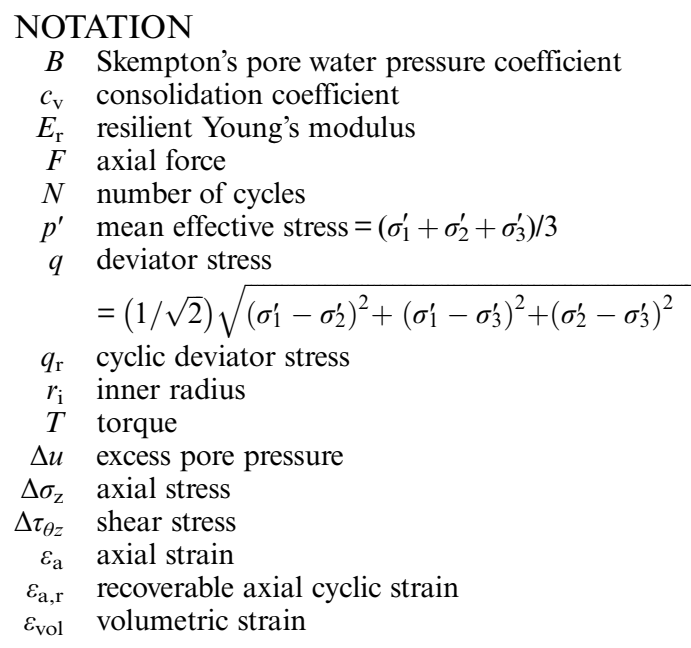

\section{REFERENCES}

Black, D. K. \& Lee, K. L. (1973). Saturating laboratory samples by back pressure. J. Soil Mech. Found. Div. 99, No. 1, 75-93.

Brown, S. F. (1996). Soil mechanics in pavement engineering. Géotechnique 46, No. 3, 383-426, http://dx.doi.org/10.1680/ geot.1996.46.3.383.

Brown, S. F. \& Selig, E T. (1991). The design of pavement and rail track foundations. In Cyclic loading of soils: from theory to design (eds M. P. O'Reilly and S. F. Brown), pp. 249-305. London, UK: Blackie.

Brown, S. F., Lashine, A. K. F. \& Hyde, A. F. L. (1975). Repeated load triaxial testing of a silty clay. Géotechnique 25, No. 1, 95-114, http://dx.doi.org/10.1680/geot.1975.25.1.95.

Cai, Y., Yu, H. S., Wanatowski, D. \& Li, X. (2013). Noncoaxial behavior of sand under various stress paths. J. Geotech. Geoenviron. Engng 139, No. 8, 1381-1395.

Chan, F. W. K. \& Brown, S. F. (1994). Significance of principal stress rotation in pavements. In Proceedings of the 13th international conference on soil mechanics and foundation engineering, New Delhi, India, pp. 1823-1826. New York, NY, USA: Taylor \& Francis.

Chung Ip, M., Haque, A. \& Bouazza, A. (2012). Influence of cyclic stress pulse shapes on filtration behavior of railway subballast. J. Geotech. Geoenviron. Engng 138, No. 2, 230-235.

Clayton, C. R. I. \& Khatrush, S. A. (1986). A new device for measuring local axial strains on triaxial specimens. Géotechnique 36, No. 4, 593-597, http://dx.doi.org/10.1680/geot.1986.36.4.593.

Cuccovillo, T. \& Coop, M. R. (1997). The measurement of local axial strains in triaxial tests using LVDTs. Géotechnique 47, No. 1, 167-171, http://dx.doi.org/10.1680/geot.1997.47.1.167.

Georgiannou, V. N., Hight, D. W. \& Burland, J. B. (1991). Behaviour of clayey sands under undrained cyclic triaxial loading. Géotechnique 41, No. 3, 383-393, http://dx.doi.org/10.1680/ geot.1991.41.3.383

Georgiannou, V. N., Tsomokos, A. \& Stavrou, K. (2008). Monotonic and cyclic behaviour of sand under torsional loading. Géotechnique 58, No. 2, 113-124, http://dx.doi.org/ 10.1680/geot.2008.58.2.113.

Gräbe, P. J. (2001). Resilient and permanent deformation of railway foundations under principal stress rotation. $\mathrm{PhD}$ thesis, University of Southampton, Southampton, UK. 
Gräbe, P. J. \& Clayton, C. R. I. (2009). Effects of principal stress rotation on permanent deformation in rail track foundations. J. Geotech. Geoenviron. Engng 135, No. 4, 555-565.

Gräbe, P. J. \& Clayton, C. R. I. (2014). Effects of principal stress rotation on resilient behavior in rail track foundations. J. Geotech. Geoenviron. Engng 140, No. 2, 1-10.

Hight, D. W., Gens, A. \& Symes, M. J. (1983). The development of a new hollow cylinder apparatus for investigating the effects of principal stress rotation in soils. Géotechnique 33, No. 4, 355-383, http://dx.doi.org/10.1680/geot.1983.33.4.355.

Jardine, R. J., Symes, M. J. \& Burland, J. B. (1984). The measurement of soil stiffness in the triaxial apparatus. Géotechnique 34, No. 3, 323-340, http://dx.doi.org/10.1680/ geot.1984.34.3.323.

Mamou, A. (2013). Effects of principal stress rotation and drainage on the resilient stiffness of railway foundations. $\mathrm{PhD}$ thesis, University of Southampton, Southampton, UK.

Momoya, Y., Watanabe, K., Sekine, E., Tateyama, M., Shinoda, M. \& Tatsuoka, F. (2007). Effects of continuous principal stress axis rotation on the deformation characteristics of sand under traffic loads. Proceedings of the international workshop on design and construction of pavements and rail tracks Geotechnical aspects and processed materials, Osaka, Japan, pp. 77-87.

Mortezaie, A. \& Vucetic, M. (2016). Threshold shear strains for cyclic degradation and cyclic pore water pressure generation in two clays. J. Geotech. Geoenviron. Engng 142, No. 5, 04016007-1-04016007-14.

Nishimura, S., Minh, N. A. \& Jardine, R. J. (2007). Shear strength anisotropy of natural London clay. Géotechnique 57, No. 1, 49-62, http://dx.doi.org/10.1680/geot.2007.57.1.49.
O’Reilly, M. P., Brown, S. F. \& Overy, R. F. (1991). Cyclic loading of silty clay with drainage periods. J. Geotech. Engng 117, No. 2, 354-362.

Otter, L. (2011). The influence of suction changes on the stiffness of railway formation. $\mathrm{PhD}$ thesis, University of Southampton, Southampton, UK.

Powrie, W., Yang, L. A. \& Clayton, C. R. I. (2007). Stress changes in the ground below ballasted railway track during train passage. Proc. Instn Mech. Engrs, Part F: J. Rail Rapid Transit 221, No. 2, 247-261.

Priest, J. A., Powrie, W., Yang, L., Gräbe, P. J. \& Clayton, C. R. I. (2010). Measurements of transient ground movements below a ballasted railway line. Géotechnique 60, No. 9, 667-677, http://dx.doi.org/10.1680/geot.7.00172.

Saada, A. S. \& Townsend, F. C. (1981). State of the art: Laboratory strength testing of soils. In Laboratory shear strength of soil (eds R. N. Yong and F. C. Townsend), ASTM STP No. 740, pp. 7-77. West Conshohocken, PA, USA: ASTM International.

Sayao, A. \& Vaid, Y. P. (1991). A critical assessment of stress nonuniformities in hollow cylinder test specimens. Soils Found. 31, No. 1, 60-72.

Shahu, J. T., Yudhbir \& Kameswara Rao, N. S. V. (1999). A simple test methodology for soils under transportation routes. Géotechnique 49, No. 5, 639-649, http://dx.doi.org/10.1680/ geot.1999.49.5.639.

Tatsuoka, F., Sonoda, S., Hara, K., Fukushima, S. \& Pradhan, T. B. S. (1986). Failure and deformation of sand in torsional shear. Soils Found. 26, No. 4, 79-97.

Zdravkovic, L. \& Jardine, R. J. (1997). Some anisotropic stiffness characteristics of a silt under general stress conditions. Géotechnique 47, No. 3, 407-437, http://dx.doi.org/10.1680/geot.1997.47.3.407. 